\title{
Congenital Malformations: a Prevalence Study in the City of Sousa, Paraíba, Between 2012 and 2014

Ocilma Barros de Quental ${ }^{2}$, Ágatha Barbosa de Paula ${ }^{1}$, Jennifer Yohanna Ferreira de Lima Antão ${ }^{2}$, Hermes Melo Teixeira Batista ${ }^{2,3}$, Ankilma do Nascimento Andrade Feitosa', Maria Iranilda Silva Magalhães ${ }^{1}$, Tatiana Alves Oliveira ${ }^{2}$, Renata Lívia Silva Fonseca Moreira de Medeiros', Cicero Macêdo Cruz², Italla Maria Pinheiro Bezerra2', Luiz Carlos de Abreu²

\section{Abstract}

Introduction: Congenital malformations, also called Congenital Anomalies (CA) or birth defects are morphological and/or functional changes evident at birth or that are manifested at later stages of life. The origin of most CA is still unknown, but the causes may be related to genetic and environmental factors.

Objetive: Identify the prevalence of congenital malformations in the city of Sousa, Paraíba, between 2012 and 2014.

Method: This is a cross-sectional and descriptive study conducted in the city of Sousa, Paraíba, Brazil, based on data extracted from the Computing Department of the Unified Health System (DATASUS) and the Live Birth declarations (DNVs) supplied by the Department of Epidemiological Surveillance of the Municipal Secretary of Health from the above-mentioned city. Data were tabulated in Microsoft Office Excel 2013 software. Furthermore, a database in SPSS (version 21) was built. We used descriptive analysis of frequency and percentage and as inferential technique, we used logistic regression and the level of statistical significance set at 5\% with $95 \%$ confidence intervals for each independent variable analyzed.

Results: It was evident that there was a prevalence of $0.48 \%$ of Congenital Malformations cases. Among the abnormalities, the most frequent were the ones in the osteomuscular system (35.7\%), followed by abnormalities of the nervous system (28.6\%). The groups that showed statistical significance in relation to the presence of abnormality were: considered late mothers and had an odds ratio of 5.50, mothers who
1 Faculdade Santa Maria (FSM). Cajazeiras (PB), Brazil.

2 Laboratório de Delineamento e Escrita Científica. Departamento de Morfologia e Fisiologia, Faculdade de Medicina do $A B C$. Santo André, SP, Brazil.

3 Faculdade de Medicina Estácio, Juazeiro do Norte, Ce, Brazil.

Contact information:

Hermes Melo Teixeira Batista.

$\equiv$ hermesmelo@oi.com.br 
had a gestational age lower than 37 weeks who showed an odds ratio of 4.21 and with relation to the Apgar score of below 7 with 5.70 chances of occurrence of the event. Male newborns, cesarean delivery and babies with normal weight, were predominant in the study, presented as $54.5 \%, 81.8 \%$ and $90 \%$, respectively. Taking into account the following parameters: mothers with adequate number of prenatal consultations, well-educated and married were most affected by the event.

Conclusion: The prevalence of malformations in the city of Sousa, PB, Brazil decreased between the years of 2012 and 2014, however, the study shows data that is relevant to public health, for the reorientation of health practices and decision making in health after the identification of the relationship of occurrence of these malformations and some variables, such as maternal age, gestational age and Apgar score.

\section{Keywords}

Congenital Malformation; Prevalence; Teratogenicity.

\section{Introduction}

Congenital malformations, also called Congenital Anomalies (CA) or congenital defects are morphological and/or functional changes detectable at birth or that are manifested at later stages of life. The morphological or anatomical changes exhibit very diverse clinical manifestations, from mild dysmorphisms highly prevalent in the population to extremely rare and complex defects of organs or body segments. These defects may present themselves alone or in combination, comprising syndromes of genetic and/or environmental causes [1].

It is estimated that an average of 50 to $60 \%$ of congenital malformations are of unknown origin, the remainder can be attributed to chronic exposure to environmental factors, chemical agents (drugs and medicines), biological (maternal infections), physical (radiation exposure), genetic disorders or multifactorial [2]. It is important to note that this prolonged exposure can also affect maternal health, causing miscarriages and infertility $[3,4]$.

The lack of official data in Brazil related to congenital malformations complicates the work of the researchers. The overall incidence of birth defects in Brazil does not differ from that found in other regions of the world and, generally $2-5 \%$ of Brazilian newborns have congenital defects [5]. Those with less extreme genotypic errors, enabling a complete embryonic development and a live birth that ranges from small asymmetries to defects with greater aesthetic and functional impairment of the child [6].

After years of study, finally, the Human Genome Project is complete, in other words, the draft of the sequence of the human genome. In addition, from this discovery, the researchers assume that the secret for a predisposition to diseases is the response to environmental agents and drugs, factors that are closely associated with the origin of congenital anomalies and is coded in around $0.1 \%$ of the DNA. However, despite the advances in Medical and Molecular Genetics and the emergence of genomics (study of all the genes in the genome and their interactions), this $0.1 \%$ of the DNA is somewhere around three million base pairs, making the origin of congenital anomalies partially unclear [7].

All populations are at risk of developing congenital malformations, however, the frequency and type 
of these anomalies vary with race, ethnicity and socioeconomic conditions, as well as with access to health services, nutrition, lifestyle and maternal education [8].

From the Sistema de Informação sobre Nascidos Vivos (SINASC), data related to the prevalence of congenital malformations can be easily obtained through the Live Birth Declaration (DNV). Therefore, it is important to periodically assess the quality of data from the information systems because from the epidemiological profile of the region, managers of the health sector can improve or even restructure the policies of support to the population by investing in the training of professionals and preventive measures, thereby reducing some risk factors.

Population studies about malformations are rare in Brazil and are limited to hospital data that make up the Latin American Collaborative Study of Congenital Malformations (ECLAMC). Created in 1967, the ECLAMC aims to register the congenital anomalies in live or stillborn babies and to promote health policies for the establishment of preventive measures of such developmental abnormalities. The ECLAMC was adopted as the gold standard to assess the criterion validity of diagnoses of congenital anomalies in SINASC [9].

The knowledge about the prevalence of congenital malformations becomes of great importance to public health, since these problems can be avoided in most cases when you have a care of good quality, with actions of prevention, instituted from the prenatal in order to reduce cases of neonatal and perinatal mortality.

The lack of concrete data regarding the incidence and/or prevalence of defects limits the studies that could be deeper in order to discover more effective prevention strategies. Thus, the objective was to describe the prevalence of congenital malformations in the city of Sousa, Paraíba, Brazil, between 2012 and 2014.

\section{Method}

It is a cross-sectional and descriptive study conducted in the city of Sousa - Paraíba, Brazil. Based on data extracted from the Computing Department of the Unified Health System (DATASUS) [10] and Live Birth Declarations (DNVs) supplied by the Department of Epidemiological Surveillance of the Municipal Secretary of Health of the above-mentioned city [11].

The city of Sousa, located in the high hinterlands of the state of Paraíba, according to the Instituto Brasileiro de Geografia e Estatística (IBGE) [12], in 2010, had a population of about 65803 people and a land area of $738547 \mathrm{~km}^{2}$. The population density of the region is of 89.10 people/ $\mathrm{km}^{2}$ and the Human Development Index of the city is 0.668 .

The criteria adopted for the constitution of the population were: all newborns with some CA (congenital anomaly) from mothers residing in the city of Sousa and born in the period of 2012-2014.

Therefore, because of the size of the population, the infeasibility to analyze it in its entirety, we used samples for convenience. This sample of 310 cases came from random selection of DNVs related to the studied period in order to estimate possible factors associated with the event (Table 1).

For calculation purposes, we only considered the data of newborns whose records from the DNVs about "Congenital malformation and/or Chromosomal Anomaly" were fulfilled.

The outcome variable (dependent) has been the presence and identification of the CA. The independent variables analyzed in this study were categorized into maternal variables: age, divided into tee-

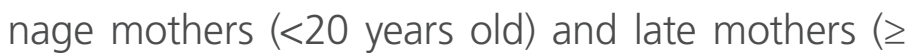
35 years old); marital status, such as married (with consensual union) or not married (single, widowed and divorced); categorized education as less than eight years of study and eight or more years of study; length of pregnancy as less than 37 weeks and equal to or greater than 37 weeks, number of prenatal consultations (less than seven consultations and seven or more visits) and the type of delivery (normal or cesarean). 
Table 1. Characteristics of mothers and babies from the city of Sousa, Paraíba, Brazil, 2014.

\begin{tabular}{|c|c|c|}
\hline & $\underline{\mathbf{n}}$ & $\%$ \\
\hline \multicolumn{3}{|l|}{ Birth Year } \\
\hline 2012 & 100 & 32.3 \\
\hline 2013 & 107 & 34.5 \\
\hline 2014 & 103 & 33.2 \\
\hline \multicolumn{3}{|l|}{ Presence of Congenital Anomaly } \\
\hline Absence & 299 & 96.5 \\
\hline Presence & 11 & 3.5 \\
\hline \multicolumn{3}{|l|}{ Maternal Age } \\
\hline Between 20 and 34 years old & 189 & 61.0 \\
\hline Below 20 years old & 73 & 23.6 \\
\hline Above 34 years old & 47 & 15.2 \\
\hline \multicolumn{3}{|l|}{ Marital Status } \\
\hline Married & 212 & 73.9 \\
\hline Not married & 75 & 26.1 \\
\hline \multicolumn{3}{|l|}{ Education } \\
\hline Below 8 years & 84 & 28.1 \\
\hline 8 years or above & 215 & 71.9 \\
\hline \multicolumn{3}{|l|}{ Gestational Age } \\
\hline Below 37 weeks & 39 & 12.8 \\
\hline 37 weeks or above & 265 & 87.2 \\
\hline \multicolumn{3}{|l|}{ Prenatal Consultation } \\
\hline Below 7 consultations & 95 & 31.0 \\
\hline 7 consultations or above & 211 & 69.0 \\
\hline \multicolumn{3}{|l|}{ Type of Delivery } \\
\hline Normal & 45 & 14.7 \\
\hline Cesarean & 261 & 85.3 \\
\hline \multicolumn{3}{|l|}{ Gender } \\
\hline Male & 165 & 53.2 \\
\hline Female & 145 & 46.8 \\
\hline \multicolumn{3}{|l|}{ Race } \\
\hline White & 46 & 56.1 \\
\hline Non-White & 36 & 43.9 \\
\hline \multicolumn{3}{|l|}{ Birth Weight } \\
\hline Normal & 278 & 89.7 \\
\hline Underweight & 29 & 9.4 \\
\hline \multicolumn{3}{|l|}{ Apgar Score at 5 minutes } \\
\hline 7 or below & 13 & 4.3 \\
\hline Above 7 & 291 & 95.7 \\
\hline
\end{tabular}

The Newborn Variables were the gender (female and male), race (white and non-white whereas for the non-white we include black, yellow, brown and Indian), Apgar score at five minutes (less than seven and equal to or greater than seven) and birth weight classified as normal when equal or greater than 2, $500 \mathrm{~g}$. and underweight, when it is less than 2, 500 grams [13].

A database was built in SPSS (version 21). We used descriptive analysis of frequency and percentage and as inferential technique we used logistic regressions.

Data were tabulated in Microsoft Office Excel 2013 software. A database in SPSS (version 21) was also built. We used descriptive analysis of frequency and percentage and as inferential technique we used logistic regression and the level of statistical significance set at 5\% with 95\% confidence intervals for each independent variable analyzed. Then, tables were created providing the data obtained as a percentage. Table 2 presents the bivariate regressions that estimate, through the exponential $B$, the gross odds ratios of being born with abnormalities and their confidence intervals. Those variables that showed statistical significance (represented by "p") greater than or equal to 0.2 were considered in the multivariate model, with adjusted odds ratios. Table 3 shows this model, where $p$ values below than or equal to 0.05 were accepted as significant.

The declarations with the field of presence or absence of abnormalities not fulfilled and the number of cases considered ignored, were quantified and used as an indicator of quality of data.

This study was approved by the Research and Ethics Committee of the Santa Maria College, under No. 1027244/2015 according to what is established in Resolution 466/12 of the National Health Council [14].

\section{Results and Discussion}

To calculate the prevalence of births with congenital anomalies during the studied period, we used the 


\section{INTERNATIONAL ARCHIVES OF MEDICINE

Table 2. Bivariate model of variable associated with abnormalities in newborns. Sousa, Paraíba, Brazil, 2012-2014.

\section{Independent variables}

\begin{tabular}{|c|c|c|c|}
\multicolumn{2}{|c|}{ Anomalies } & & OR \\
Absence & Presence & & OR \\
Gross
\end{tabular}

CI $95 \%$

Maternal age

Between 20 and 34 years old ref.

Below 20 years old

$185(97.9 \%) \quad 4(2.1 \%)$

Above 34 years old

$71(97.3 \%)$

$2(2.7 \%)$

0.76

1.30

$0.13 / 7.27$

Marital status

Married ref.

$42(89.4 \%)$

$5(10.6 \%)$

0.01

5.50

$1.42 / 21.38$

Not married

$203(95.8 \%) \quad 9(4.2 \%)$

$73(97.3 \%)$

$2(2.7 \%)$

0.54

0.62

$0.13 / 2.93$

Education

Below 8 years ref.

8 years or above

\begin{tabular}{c|l}
$83(98.8 \%)$ & $1(1.2 \%)$ \\
$206(95.8 \%)$ & $9(4.2 \%)$
\end{tabular}

0.22

3.63

$0.45 / 29.07$

Gestational Age

37 weeks or above ref.

Below 37 weeks

\begin{tabular}{c|c|}
\hline $35(89.7 \%)$ & $4(10.3 \%)$ \\
$258(97.4 \%)$ & $7(2.6 \%)$
\end{tabular}

0.03

4.21

$1.17 / 15.12$

Prenatal consultation

Below 7 ref.

7 consultations or above

$90(94.7 \%)$

$5(5.3 \%)$

$205(97.2 \%) \quad 6(2.8 \%)$

0.30

0.53

$0.16 / 1.77$

Type of delivery

Normal ref.

Cesarean

$43(95.6 \%)$

$2(4.4 \%)$

$252(96.6 \%) \quad 9(3.4 \%)$

0.74

0.77

$0.16 / 3.68$

Gender

\begin{tabular}{|c|c|c|c|c|c|}
\hline Male ref. & 159 (96.4\%) & $6(3.6 \%)$ & & & \\
\hline Female & 140 (96.6\%) & $5(3.4 \%)$ & 0.93 & 0.95 & $0.28 / 3.17$ \\
\hline Race & & & & & \\
\hline White ref. & 44 (95.\%) & $2(4.3 \%)$ & & & \\
\hline Non-white & $36(100 \%)$ & $0(0.0 \%)^{* *}$ & & & \\
\hline Weight & & & & & \\
\hline Normal ref. & $268(96.4 \%)$ & $10(3.6 \%)$ & & & \\
\hline Underweight & $28(96.6 \%)$ & $1(3.4 \%)$ & 0.97 & 0.96 & $0.12 / 7.75$ \\
\hline Apgar score at & & & & & \\
\hline Above 7 ref. & 282 (96.9\%) & $9(3.1 \%)$ & & & \\
\hline 7 or below & $11(84.6 \%)$ & $2(15.4 \%)$ & 0.04 & 5.70 & $1.10 / 29.55$ \\
\hline OR - Odds Rat & & Ref. Reference & ories. & & \\
\hline ** Unable to $\epsilon$ & nissing values. & Cl 95\% - Con & e inte & $5 \%$ of & \\
\hline
\end{tabular}


Table 3. Multivariate model of the association of variables with abnormalities in newborns. Sousa, Paraíba, Brazil, 2012-2014.

\begin{tabular}{|c|c|c|c|c|c|c|}
\hline \multirow{2}{*}{ Independent variables } & \multirow{2}{*}{ Wald test } & \multirow{2}{*}{$\begin{array}{l}\text { Degrees of } \\
\text { freedom }\end{array}$} & \multirow{2}{*}{ Sig. } & \multirow{2}{*}{$\begin{array}{c}\text { OR } \\
\text { adjusted }\end{array}$} & \multicolumn{2}{|c|}{ Cl $95 \%$} \\
\hline & & & & & Inferior & Superior \\
\hline \multicolumn{7}{|l|}{ Maternal age } \\
\hline \multicolumn{7}{|l|}{ Between 20 and 34 years old ref. } \\
\hline Below 20 years old & 0.10 & 1 & 0.75 & 1.32 & 0.23 & 7.61 \\
\hline Above 34 years old & 5.19 & 1 & 0.02 & 5.02 & 1.25 & 20.16 \\
\hline \multicolumn{7}{|l|}{ Gestational age } \\
\hline \multicolumn{7}{|l|}{37 weeks or above ref. } \\
\hline Below 37 weeks & 3.40 & 1 & 0.06 & 3.62 & 0.92 & 14.23 \\
\hline \multicolumn{7}{|l|}{ Education } \\
\hline Below 8 years ref. & $83(98.8 \%)$ & $1(1.2 \%)$ & & & & \\
\hline 8 years or above & 206 (95.8\%) & $9(4.2 \%)$ & 0.22 & 3.63 & & \\
\hline \multicolumn{7}{|l|}{ Apgar score $5^{\circ}$ minute } \\
\hline \multicolumn{7}{|l|}{ Above 7 ref. } \\
\hline 7 or below 7 & 1.58 & 1 & 0.20 & 3.15 & 0.52 & 18.89 \\
\hline OR - Odds Ratio & & \multirow{2}{*}{\multicolumn{5}{|c|}{$\mathrm{Cl} 95 \%$ - Confidence interval of $95 \%$ of the OR }} \\
\hline Ref. Reference categories. & & & & & & \\
\hline
\end{tabular}

data contained in the Computing Department of the Unified Health System (DATASUS) [10]. From this assumption, it was found that in the period of 20122014 there were 2924 births in the city of Sousa, Paraíba, Brazil where a frequency of $0.48 \%$ of the cases presented Congenital Malformations.

The proportion of newborns with some malformation in the city studied is similar to that found in other studies that showed rates from 0.4 to $0.8 \%$ of live births $[15,16]$.

Due to the size of the population, therefore, there is an infeasibility to analyze it in its entirety, we then used samples for convenience, this sample was of 310 cases to estimate possible factors associated with the event (Table 1).

The data show that mothers who had children when they were aged between 20 to 34 years old, considered out of risk, are married $(73.9 \%)$, with 8 or more years of education, with 37 weeks or more of pregnancy $(87.2 \%), 69 \%$ had a satisfactory number of prenatal consultations, $85.3 \%$ with cesarean delivery, 53.2\% with male babies, $56.1 \%$ white, 89.7\% with normal weight and $95.7 \%$ with Apgar score at 5 minutes greater than 7 (Table 1). The percentages were calculated from the sample.

In addition to the information accessed from the DATASUS [10], we also analyzed about 5462 Live Birth Declarations (DNV) related to births in the city of Sousa, Paraíba, in the period from 2012 to 2014. Out of the total, the presence or absence of abnormalities field was not filled in around $11 \%$ of the records, in other words, there was no completeness with relation to the field 34 of the DNV.

Other studies showed higher percentages, such as the one carried out in 2007 in the city of Maringá, Paraná, with underreporting of $22.8 \%$ [16]; and other smaller percentages as study realized in Vale Paraíba Paulista in 2002 and 2003 which found $1.5 \%$ of underreporting for congenital anomalies [15]. Important fields such as mother's age, duration of pregnancy, number of prenatal visits are essential information to identify risk factors for birth defects, which leads us to emphasize the importance of training employees responsible for filling the DNV. 
Inconsistencies were identified between data from DNV filed with the ES (Epidemiological Surveillance) of the city and the ones published by SINASC. According to the DATASUS, in 2013 five children were born with some congenital malformation from mothers living in the city, however, for the same period, the data stored in the ES indicate the birth of six children with CA. Besides this, nine out of all the cases, had field 34 of the DNV marked as "unknown", characterizing them as under-reporting cases.

Table 2 shows the bivariate model of the association of variables with abnormalities in newborns. Three variables showed significant associations. Mothers who had their babies after 34 years old had an odds ratio of 5.50 of having a baby with abnormalities $(p=0.01)$.

Similar outcome on this maternal variable was found in a study [17] in which there is significant prevalence of malformations among women younger than or equal to 14 years old (11/100.000) and among the ones older than or equal to 35 years old (10. 4/100.000).

This study also corroborates with research realized in Bugando in Tanzania, reporting that maternal age above 35 years old, the lack of periconceptional use of folic acid, little or no visit to the antenatal clinic and maternal exposure to pollutants were maternal factors found to be associated with congenital anomalies [18].

However, it does not match with Melo's findings [16] which with relation to the distribution of cases of CA by maternal age group, reported less frequent occurrence in mothers who were teenagers (26.4\%) and late mothers (13.4\%).

Gestational age and Apgar score showed significant values, therefore, they were considered risk factors for congenital malformation. With regards to the gestational period, mothers who had a gestational age below 37 weeks showed chances of 4.21 times $(p=0.03)$, as well as in relation to Apgar score of below 7 with an odds ratio of 5.70 of having a baby with abnormalities $(p=0.04)$.
These results coincide with those found in three studies with similar proposals. A survey done in a public hospital in Bahia [19], claiming greater frequency in premature babies (56.7\%), another in the state of Rio de Janeiro between 2000 and 2006 with 23.9 CA per 100.000 born, as well as a study performed by Pinto and Nascimento [15] which showed a statistically significant proportion $p<0.001$.

The latter also showed impressive results with relation to low Apgar score associated with the presence of CA. However, there are disagreements with other studies that even in relation to Apgar score at 5 minutes, $85.3 \%$ of newborns with CA present a value $\geq 7$, held in Maringá between 2000 to 2007 [16]. Apgar score refers to a particular important data to assess the newborn's condition as an index of less than 7 may indicate bad extrauterine adaptation, requiring more assistance.

In this study, these three variables, maternal age, gestational age and Apgar score, were taken into account in a multivariate model.

Regarding the other variables, cesarean deliveries proved to be the most prevalent (81.8\%). Another study conducted in Vitória/ES [20] points out that the number of cesarean deliveries was significantly higher in the newborn group that had congenital malformation, about $72 \%$ were born by cesarean delivery. The same is found in an assessment made by the SINASC from the city of Rio de Janeiro [21].

Prenatal visits below 7 (10\%), the education level below 8 years (45.5\%) and single marital status $(18.1 \%)$ were maternal variants that in this study did not present significance with the presence of CA because they showed percentages lower than of mothers of children with malformations. The same applies to the weight considered normal, in other words, greater than $2.500 \mathrm{~g}$ which the frequency was higher than $90 \%$. These findings corroborate to the studies of Melo [16]. However, differs from those of Guerra [21] which found that pregnant women who received less prenatal consultations ( $\leq$ 6) and newborns weighing less than $2.500 \mathrm{~g}$ also showed higher proportion of birth defects. 
With regards to the gender, according to DNV's retained in the Department of Epidemiological Surveillance of the city, $54.5 \%$ of the cases were predominantly in males. The same result was found in similar studies [22, 19, 17 and 15].

In approximately $74 \%$ of the declarations analyzed in this study, there was no specific field requesting the newborn race, especially the ones for the years of 2012 and 2013. Thus, the correlation of ethnic conditions of the newborn with the existence of congenital malformation was made impossible. In another study, a high frequency of minor malformations in babies of black race was observed, which are those that have no functional implications or cosmetic importance, such as simian crease, syndactyly and supernumerary fingers and major and multiple malformations in Caucasians, which are lethal anomalies or that significantly affect the function or appearance, requiring medical or surgical treatment [8].

The last table (Table 3 ) presents the multivariate model of the association of variables with the abnormality in newborns. Only the variable of maternal age continued with statistical significance, showing its importance with relation to the other variables. The gestational age should also be mentioned because for very little it did not continue with statistical significance $(p=0.06)$.

The types of identified congenital malformations, according to the ICD-10 [23] were described and grouped into any of the following groups of causes: central nervous system (ICD10 Q00.0 to Q07.9), cardiovascular system (ICD10 Q20.0 the Q28.9), the musculoskeletal system disorders (ICD-10 Q66.0 to Q79.9), urogenital system (ICD-10 Q60.0 to Q64.9), pulmonary system (ICD-10 Q30.0 to Q34.9), cleft lip and palate (ICD10 Q35.9 to Q37.9), digestive system (ICD-10 Q38.2 to Q45.9) congenital anomalies of ear, face and neck (ICD10 Q15.0 and Q18.8), chromosomal abnormalities (ICD-10 Q90.0 the Q99.9) and other anomalies (ICD-10 Q80.0 to Q89.9).

Among the defects, the most frequent were the ones in the musculoskeletal system (35.7\%), espe- cially malformations in the foot or "clubfoot" and in sequence, nervous system abnormalities (28.6\%), mainly anencephaly. Genitourinary and chromosomal anomalies (trisomy 21) had equal proportions of $14.3 \%$. Children born with other birth defects accounted for only $7.1 \%$ of cases.

The above findings are similar to the study performed in 34 maternities from Rio de Janeiro which showed higher frequency of abnormalities on the musculoskeletal system, central nervous system, cleft palate and genitourinary system respectively $[16,21]$. This also corroborates to the findings from a university hospital of Mato Grosso [24].

It is really important to know the rates and causes of congenital malformations as it provides aid for public authorities and help them with decisionmaking in front of the actions to be taken to reduce or eliminate such anomalies.

However, it is important that these women are stimulated early to perform prenatal consultations with the purpose to identify possible malformation problems during the gestation period, which may prevent possible future complications. Thus, the systematic action performed by governments and partner organizations is needed to reach the population, for example of the women and newborns with a view to an effective care [25].

However, one limitation of the study was the identification of incompatibility of results between the DATASUS and DNV, and the failure to complete more than $11 \%$ of these forms on the field presence or absence of abnormalities, which may imply to a need to implement courses and training of staff involved from the ones involved with completion of the forms to the staff feeding the system. This will lead to a significant reduction in underreporting.

Thus, it was found that in the period of 20122014 there were 2924 births from mothers living in Sousa and there was a frequency of $0.48 \%$ of Congenital Malformations cases. Still of decreasing characteristics, being $0.69 \%$ in $2012,0.53 \%$ in 2013 and a lower proportion in 2014 with only 
$0.20 \%$ cases of congenital anomalies. Among the defects, the most frequent were the ones in the musculoskeletal system (35.7\%), mainly malformations in the foot or "clubfoot" and in sequence, nervous system abnormalities (28.6\%), mainly anencephaly.

There is a close relationship between the occurrence of malformations among the variables: maternal age, gestational age and Apgar score. The ones considered late mothers (age $\geq 35$ years old) had 5.50 times more chances of having a baby with abnormalities $(p=0.01)$. In relation to the gestational age, mothers who had gestational age below 37 weeks showed 4.21 times more chances $(p=$ $0.03)$, as well as in relation to Apgar score below 7 with 5.70 more chances of having a baby with abnormalities ( $p=0.04$ ).

Male newborn and cesarean delivery were the predominant variables in the study, with 54.5\% and $81.8 \%$, respectively. Prenatal consultations below seven (10\%), and the level of education below eight years (45.5\%) were maternal variants that in this study did not present significance with the presence of CA as they had percentages lower than of mothers with children with malformations. The same applies to the weight considered normal, in other words, greater than $2500 \mathrm{~g}$ which the frequency was higher than $90 \%$.

It was found that in the period of 2012 to 2014 there were 2924 births to mothers living in Sousa, which had a frequency of $0.48 \%$ of Congenital Malformations cases. A decrease of the characteristics of the event occurring between the years studied was observed, the year 2012 was the one with higher frequency.

Among the defects, the most frequent were the ones in the musculoskeletal system mainly malformations in the foot or "clubfoot" and in sequence, abnormalities of the nervous system, mainly anencephaly.

There is a close relationship between the occurrence of defects and the variables: maternal age, gestational age and Apgar score.
The incompatibility of results between the DATASUS and DNV and the failure to complete the forms in the field for presence or absence of anomalies, the need to implement courses and training of the staff involved from the completion of the declarations to the ones feeding the system is to be highlighted. This could lead to a significant reduction in underreporting.

It is important to periodically evaluate the quality of data from information systems, as it is believed that producing relevant information for surveillance and epidemiological investigation of congenital anomalies, managers of the health sector can improve or even restructure the policies of support to the population, investing in the training of professionals and facilitating the implementation of preventive measures, thereby reducing some risk factors for birth defects.

\section{References}

1. São Paulo. Secretaria Municipal da Saúde. Coordenação de Epidemiologia e Informação - CEInfo. Declaração de Nascido Vivo - Manual de Anomalias Congênitas. $2^{\text {a }}$ ed. São Paulo: Secretaria Municipal da Saúde, 2012. 97p.

2. Ive C; Oliveira F; Richieri-costa A; Cristina V; Ferrarese C; Cristina $D$. Birth defects in newborns and stillborns: an example of the Brazilian reality. BMC. Vol. 4, p 343, 2011.

3. Pinto, LA; Nunes, GG; Bacha, OM; Soares, CRS; Stein, NR; Minussi, L; Sanseverino, MTV; Faccini, LS. Fatores de risco para malformações congênitas, baixo peso ao nascimento e perdas gestacionais na população dos municípios de Montenegro e Triunfo/RS. Salão de Iniciação Científica (10.: 1998: Porto Alegre). Livro de resumos. Porto Alegre: UFRGS, 1998. Disponível em: http://hdl.handle.net/10183/90031.

4. Leite, JCL; Schüler-Faccinib, L. Defeitos congênitos em uma região de mineração de carvão. Rev Saúde Pública. Vol.35, n. 2, p 136-141, 2001.

5. Nhoncanse GC, Melo DG. Confiabilidade da Declaração de Nascido Vivo como fonte de informação sobre os defeitos congênitos no Município de São Carlos, São Paulo, Brasil. Ciênc. saúde coletiva. 2012; 17(4): 955-963.

6. Santos RS, Dias IMV. Refletindo sobre a malformação congênita. Rev. Bras. Enferm. 2005; 58(5): 592-596.

7. Kumar, V; Abbas, A. K; Fausto; Aster, JC. N. Robinns e Conttran: Patologia - Bases Patológicas das Doenças/ [editores] Kuma, Abbas, Fausto, Aster; [tradução Maria da Conceição Zacharias... et al.]. - 8a ed. Rio de Janeiro: Elsevier, 2010. 
8. Arruda TAM, Amorin MMR, Souza ASR. Mortalidade determinada por anomalias congênitas em Pernambuco, Brasil, de 1993 a 2003. Rev. Assoc. Med. Bras. 2008; 54(2): 122-126.

9. Luquetti DV, Koifman RJ. Qualidade da notificação de anomalias congênitas pelo Sistema de Informações sobre Nascidos Vivos (SINASC): estudo comparativo nos anos 2004 e 2007. Cad. Saúde Pública. 2010; 26(9): 1756-1765.

10. Brasil, Ministério da Saúde. Banco de dados do Sistema Único de Saúde - DATASUS, Sistema de Informação de Nascidos Vivos. Disponível em http://tabnet.datasus.gov.br/cgi/deftohtm. exe?sinasc/cnv/nvpb.def

11. Sousa. Departamento de Vigilância Epidemiológica da Secretaria Municipal de Saúde de Sousa- Paraíba- Brasil. 2014.

12. Instituto Brasileiro de Geografia e Estatística (IBGE). Dados Demográficos do Município de Sousa- Paraíba- Brasil, 2010.

13. Brasil. Ministério da Saúde. Secretaria de Atenção à Saúde. Departamento de Ações Programáticas Estratégicas. Manual Técnico de Atenção Humanizada à Recém-Nascido de Baixo Peso: Método Canguru. $2^{a}$ ed. Brasília: Secretaria Municipal de Saúde, 2011. 204 p.

14. Conselho Nacional de Saúde. Ministério da Saúde. Resolução 466, de 12 de Dezembro de 2012.

15. Pinto, CO; Nascimento, LFC. Estudo de prevalência de defeitos congênitos no Vale do Paraíba Paulista. Rev. Paul Pediatr. Vol. 25, n. 3, p. 233-239, 2007.

16. Melo WA, Zurita RCM, Uchimura TT, Marcon, SS. Anomalias congênitas: fatores associados à idade materna em município sul brasileiro, 2000 a 2007. Revista Eletrônica de Enfermagem. 2010; 12(1): 73-82.

17. Reis, AT; Santos, RS; Mendes, TAR. Prevalência de Malformações Congênitas no Município do Rio de janeiro, Brasil, entre 2000 e 2006. Rev. Enferm. UERJ, Rio de Janeiro, vol. 19, n. 3, p 364 a 368, 2011.

18. Mashuda F, Zuechner A, Chalya PL, Kidenya BR, Manyama M. Pattern and factors associated with congenital anomalies among young infants admitted at Bugando medical centre, Mwanza, Tanzania BMC Research Notes 2014, 7:195 doi:10.1186/17560500-7-195

19. Ramos, AP; Oliveira, MND; Cardoso, JP. Prevalência de malformações congênitas em recém-nascidos em hospital da rede pública. Rev. Saúde. Com. Vol. 4, n. 1, p 27-42, 2008.

20. Maciel E, Gonçalves EP, Alvarenga VA, Polone CT, Ramos MC. Perfil epidemiológico das malformações congênitas no município de Vitória - ES. Cad saúde colet. vol. 14, n. 2, p. 507 a 518, 2006

21. Guerra, FAR; Júnior, JCL; Gama, SGN; Cunha, CBC; Filha, MMT. Defeitos congênitos no Município do Rio de Janeiro, Brasil: uma avaliação através do SINASC (2000-2004). Cad. Saúde Pública, Rio de Janeiro, 24(1): 140-149, jan, 2008.
22. Gianicolo, EAL; Bruni, A; Rosati, E; Sabina, S; Guarino, R; Padolecchia, G; Leo, C; Vigotti, MA; Andreassi, MG; Latini, G. Congenital anomalies among live births in a polluted area. A ten-year retrospective study. BMC Pregnancy an Childbirth. 12:165, 2012. Disponível em: http://www.biomedcentral. com/1471-2393/12/165

23. Organização Mundial de Saúde. Classificação estatística internacional para doenças e problemas relacionados à saúde (CID-10). São Paulo: Centro colaborador da OMS para a Classificação das doenças em português. Décima revisão. Versão 2008. [citado em 13 abr 2009]. Disponível em: http://www.datasus.gov.br/cid10/v2008/web help/cid10.htm

24. Galera MF, Serafini C, Matos TC, Camacho P, Araújo C, Duarte EC, Galera BB. Vigilância epidemiológica de anomalias congênitas em um hospital universitário de Mato Grosso, Brasil. Rev. Pediatria. 2010; 32(1): 28-36.

25. Atrash HK. Childhood mortality: still a global priority. Journal o f Human Growth and Development, 2013; 23(3): 257-260.

\section{Comment on this article:}

\section{A 8 in $8+\mathbf{S} P$}

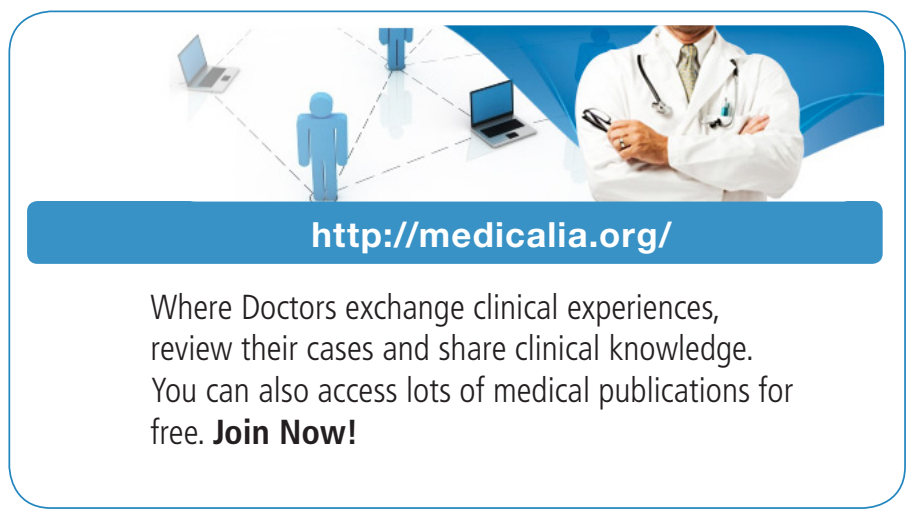

\section{Publish with iMedPub}

\section{http://www.imed.pub}

International Archives of Medicine is an open access journal publishing articles encompassing all aspects of medical science and clinical practice. IAM is considered a megajournal with independent sections on all areas of medicine. IAM is a really international journal with authors and board members from all around the world. The journal is widely indexed and classified Q1 in category Medicine. 